\title{
Leaching Behaviour of Combination Product (Novaluron 5.25\% + Indoxacarb 4.5\% SC) at Different Depths of Sandy Loam Soil
}

\author{
Anita $^{1 *}$, V.K. Madan ${ }^{1}$, Sushil Ahlawat ${ }^{2}$ and Reena Chauhan ${ }^{2}$ \\ ${ }^{1}$ Medicinal, Aromatic and Potential Crops Section, CCS Haryana Agricultural University, \\ Hisar-125004, Haryana, India \\ ${ }^{2}$ Department of Entomology, CCS Haryana Agricultural University, Hisar-125004, \\ Haryana, India
}

*Corresponding author

\begin{abstract}
A B S T R A C T
Keywords

Leaching, Novaluron, indoxacarb, Per cent retention, Combination product, Sandy loam soil, GLC

Article Info

Accepted:

04 November 2018 Available Online:

10 December 2018

Leaching behaviour of combination product (novaluron $5.25 \%+$ indoxacarb $4.5 \% \mathrm{SC}$ ) was investigated in sandy loam soil at $43.31+37.13 \mathrm{~g}$ a.i. $\mathrm{ha}^{-1}$ (single dose) and $86.62+$ $74.26 \mathrm{~g}$ a.i. $\mathrm{ha}^{-1}$ (double dose) under laboratory conditions as per average annual rainfall of $400 \mathrm{~mm}$. Residues of novaluron and indoxacarb were estimated at different depths of soil and in leachates with the help of gas liquid chromatography (GLC) equipped with electron capture detector (ECD). Method was validated by performing recovery experiments at different spiking $\left(0.01-0.10 \mathrm{mg} \mathrm{kg}^{-1}\right)$ levels. Results revealed that maximum retention of combination product was found upto $10 \mathrm{~cm}$ soil i.e. $56.97-55.72 \%$ in novaluron and 74.36-72.20 in indoxacarb while residues reached below detectable level of $0.01 \mathrm{mg} \mathrm{kg}^{-1}$ after $40 \mathrm{~cm}$ depth of soil at both doses. Since, residues of combination product were not detected in any of the leachate fractions of soil. Hence, this combination product may be safe for soil and ground water contamination.
\end{abstract}

\section{Introduction}

Contamination of ground and surface water all over the world had become more evident over the last decade due to extent use of pesticides. Residues of insecticide, pesticides and their degradation products have frequently been detected in field groundwater monitoring programmes. As pesticides are one of the major technological developments of twentieth century, whether natural or synthetic, they have toxicological significance and pose potential risk when persist in the environment. Persistence and leaching of pesticide compounds contribute heavily to possible contamination of groundwater. The presence of insecticide residues in runoff, sediment and leachate, as well as their mobility and persistence in soil, depends on such factors as chemical and physical properties of the compound, soil properties, amount of rainfall, bed construction and the degree of slope (Halimah et al., 2005).

The indiscriminate use of pesticides has given rise to many problems viz. persistence of toxic residues in the environment, development of resistance in insect pests and resurgence of 
pests. Soil is an important component of the environment, act as a sink for the pesticides used in agriculture. Such treatments may suppress soil microflora and hence affect soil properties. The pesticides present in soil sometimes act as a source of contamination for succeeding crop also. From soil, the pesticides residues can reach to water bodies by leaching and runoff.

The main processes potentially affecting the ultimate fate of pesticides in soil are retention by soil materials (involving adsorption /desorption processes), transformation processes (biological and chemical degradation) and transport (through soil, atmosphere, surface water, or ground water) (Dagar et al., 2014). In recent years combination product or combination products are widely used by farmers as they are more effective than a single pesticide over multiple pest problems.

A relatively new benzoylphenyl urea insect growth regulator which inhibits the chitin formation on larvae of various insects (lepidoptera, coleoptera, and diptera) ie. Novaluron [( \pm -1-[3-chloro-4-(1,1,2-trifluoro2-trifluoromethoxyethoxy) - phenyl]-3-(2,6difluoro-benzoyl)urea] was developed by Makhteshim-Agan Industries Ltd. (Anita et al., 2018). Insect growth regulators (IGR) insecticides are comparatively safer to beneficial insects and environment and are compatible for use in an integrated pest management system (Ghosal et al., 2016). This compound is coming up as an ecofriendly or green pest-controlling agent (FAO, 2003).

The other insecticide indoxacarb, \{methyl 7chloro-2,5-dihydro-2-[[(methoxy-carbonyl)[4(trifluoromethoxy)phenyl]amino]carbonyl] indeno[1,2-e][1,3,4] oxadiazine-4a $(3 h)$ carboxylate \}, is a non-systemic, synthetic organophosphate replacement insecticide with broad spectrum activity and it was developed by E. I. Du Pont de Nemours Company (Pesticides, 2000). It is highly effective having low side effect on non-target insects (Michand and Grant, 2003) and allows most predators and immature wasp parasites to survive (Hewa-Kapuge et al., 2003). Since ground water is the main source of drinking and irrigation water thus to assess the risk of ground water contamination by both the insecticides, this experiment was carried out to generate information on the leaching behaviour of both the insecticides used as combination product in sandy loam soil at different doses under laboratory conditions.

\section{Materials and Methods}

Leaching studies of combination product (Novaluron + Indoxacarb) in soil were carried out under laboratory conditions during January-March 2016. Experiment was conducted in sandy loam soil collected from Research Farm of CCS HAU, Hisar. The physico-chemical properties of the soil are given in Table 1.

\section{Packing of glass column}

Plexi glass columns $(90 \mathrm{~cm} \times 2.2 \mathrm{~cm}$ i.d.) fitted with perforated plexi glass sieve covered with filter paper (Whatman No. 1) at the bottom was used for the leaching study. Each column was packed with soil up to $60 \mathrm{~cm}$ height to a uniform bulk density (BD) of 1.35 $\mathrm{g} \mathrm{cm}^{-3} \pm 0.1$. Weighed amount of soil was poured in the columns each time with the help of a funnel and tapped gently from a fixed height. This process was repeated till each column was uniformly packed to a height of $60 \mathrm{~cm}$. The soil in each column was covered with filter paper which was tapped by a glass wool swab. Soil column so filled were installed vertically on wooden stand with their bottom resting on the fixed perforated sieve, so as to facilitate collection of effluents during 
leaching. Leaching studies were carried out in triplicates. Soil was fortified with single and double dose solution of combination product. This fortified soil was added at the top of the column. Cotton swabs pre washed with acetone and dried were placed in between the column to avoid disturbance of soil. One column was packed with soil was kept as control to which no pesticide was added.

\section{Leaching of soil columns}

Each soil column was leached with $50 \mathrm{~mm}$ of water at a time with the help of pipette, with the care that no spattering of soil took place. This procedure of leaching was carried out again after $24 \mathrm{hrs}$ of the disappearance of the standing water in the column. Leaching was repeated till each leaching cycle of $400 \mathrm{~mm}$ depth was completed.

\section{Extraction and clean up}

After completion of leaching, intact soil cores were taken out of the plexi glass column. The cores were sliced in to pieces of height $10 \mathrm{~cm}$ each and air dried, grinded than soil sample is sieved through a $2 \mathrm{~mm}$ sieve and analyzed for quantification of combination product (Novaluron + Indoxacarb) residues. Leachates oozed out of all the columns were collected and processed to check the presence of combination product (Novaluron + Indoxacarb) residues. Water extract was taken in separating funnel and $4 \mathrm{~g}$ of $\mathrm{NaCl}$ was added and dissolved in it. Then extract was partitioned thrice with dichloromethane (50, $30,20 \mathrm{ml}$ ) by vigorous shaking for $5 \mathrm{~min}$ to remove the non-emulsifying impurities. Each time, organic phase was collected, passed through the $2-3 \mathrm{~cm}$ pad of anhydrous sodium sulphate and pooled together. Extract was concentrated twice with the help of rotatory vaccum evaporator in $n$-hexane and final volume made up to $2 \mathrm{ml}$. After this GLC analysis was carried out.

\section{Results and Discussion}

\section{Leaching behaviour of novaluron}

The data on leaching potential of novaluron in sandy loam soil is presented in Table 2 and figure 1 . Total amount of novaluron recovered out of 3.23 and $6.46 \mu \mathrm{g}$ were 81.16 and 79.87 per cent from single and double dose, respectively. Per cent distribution of novaluron in different soil cores (0-10, 10-20, 20-30, 30-40, 40-50 and 50-60 cm) was 56.97, $16.10,6.19$ and 1.90 per cent at single dose where in double dose 55.72, 16.87, 5.42 and 1.86 per cent, respectively. Residues reached below detectable limit after $40 \mathrm{~cm}$ depth of soil at both the doses. None of the leachate fractions from both the treatments showed the presence of novaluron residues.

\section{Leaching behaviour of indoxacarb}

Leaching potential data of indoxacarb in sandy loam soil is presented in bar diagram of figure 2 and Table 3. Total amount of indoxacarb recovered out of 2.77 and $5.54 \mu \mathrm{g}$ were 93.48 and 88.98 per cent from single and double dose, respectively. Per cent distribution of indoxacarb in different soil cores (0-10, 10-20, 20-30, 30-40, 40-50 and 50-60 cm) was 74.36, $13.71,4.69$ and 0.72 per cent at single dose while in double dose it was 72.20, 11.01, 5.23 and 0.54 per cent. Residues reached below detectable level after $40 \mathrm{~cm}$ depth of soil at both the doses. As in above case none of the leachate fractions from both the treatments showed the presence of indoxacarb residues. Eliana et al., (2009) determined the leaching behaviour of diuron in soil and water. In percolated water, diuron was detected with low frequency but in relatively high concentrations (up to $6.29 \mu \mathrm{g} \mathrm{L}^{-1}$ ). In runoff water and soil, diuron was detected in decreasing concentrations until 70 days after application, totalizing $13.9 \%$ during the whole sampling period. 
Table.1 Physico-chemical characteristics of soil

\begin{tabular}{|c|c|}
\hline Soil Type & Sandy Loam Soil \\
\hline Texture & Loam \\
\hline Ph & 7.6 \\
\hline EC $\left(\mathrm{dSm}^{-1}\right)$ & 2.0 \\
\hline O.C. $(\%)$ & 0.67 \\
\hline $\mathrm{Kc}$ & 10.08 \\
\hline $\mathrm{P}_{2} \mathrm{O}_{5}\left(\mathrm{~kg} \mathrm{ha}^{-1}\right)$ & 15 \\
\hline
\end{tabular}

Table.2 Leaching behaviour of novaluron in sandy loam soil and in leachates

\begin{tabular}{|c|c|c|c|c|}
\hline \multirow{2}{*}{$\begin{array}{c}\text { Soil } \\
\text { depth } \\
(\mathbf{c m})\end{array}$} & \multicolumn{4}{|c|}{ Novaluron Residues ( $\mu \mathrm{g}) *$} \\
\hline & $\begin{array}{c}\mathrm{T}_{1}\left(43.31 \mathrm{~g} \text { a.i. } \mathrm{ha}^{-1}\right) \\
\mu \mathrm{g} \pm \mathrm{SD}\end{array}$ & \% Retention & $\begin{array}{c}\mathrm{T}_{2}\left(86.62 \text { g a.i. } \mathrm{ha}^{-1}\right) \\
\mu \mathrm{g} \pm \mathrm{SD}\end{array}$ & $\%$ Retention \\
\hline 0-10 & $1.84 \pm 0.03$ & 56.97 & $3.60 \pm 0.28$ & 55.72 \\
\hline $10-20$ & $0.52 \pm 0.02$ & 16.10 & $1.09 \pm 0.06$ & 16.87 \\
\hline $20-30$ & $0.20 \pm 0.03$ & 6.19 & $0.35 \pm 0.03$ & 5.42 \\
\hline $30-40$ & $0.06 \pm 0.01$ & 1.90 & $0.12 \pm 0.01$ & 1.86 \\
\hline $40-50$ & BDL & BDL & BDL & BDL \\
\hline $50-60$ & - & - & - & - \\
\hline Leachate & - & - & - & - \\
\hline Total reco & ered & 81.16 & & 79.87 \\
\hline
\end{tabular}

*Average residues of three replicates

Table.3 Leaching behaviour of indoxacarb in sandy loam soil and in leachates

\begin{tabular}{|c|c|c|c|c|}
\hline \multirow{2}{*}{$\begin{array}{l}\text { Soil depth } \\
\quad(\mathrm{cm})\end{array}$} & \multicolumn{4}{|c|}{ Indoxacarb Residues ( $\mu g)^{*}$} \\
\hline & $\begin{array}{c}\mathrm{T}_{1}\left(37.13 \mathrm{~g} \text { a.i. } \mathrm{ha}^{-1}\right) \\
\mu \mathrm{g} \pm \mathrm{SD}\end{array}$ & \% Retention & $\begin{array}{c}\mathrm{T}_{2}\left(74.26 \mathrm{~g} \text { a.i. } \mathrm{ha}^{-1}\right) \\
\mu \mathrm{g} \pm \mathrm{SD}\end{array}$ & \% Retention \\
\hline 0-10 & $2.06 \pm 0.04$ & 74.36 & $4.00 \pm 0.03$ & 72.20 \\
\hline $10-20$ & $0.38 \pm 0.04$ & 13.71 & $0.61 \pm 0.06$ & 11.01 \\
\hline $20-30$ & $0.13 \pm 0.03$ & 4.69 & $0.29 \pm 0.03$ & 5.23 \\
\hline $30-40$ & $0.02 \pm 0.01$ & 0.72 & $0.03 \pm 0.01$ & 0.54 \\
\hline $40-50$ & BDL & BDL & BDL & BDL \\
\hline $50-60$ & - & - & - & - \\
\hline Leachate & - & - & - & - \\
\hline \multicolumn{2}{|c|}{ Total recovered } & 93.48 & & 88.98 \\
\hline
\end{tabular}

*Average residues of three replicates 
Fig.1 Distribution of novaluron residues at different soil depths at single and double doses

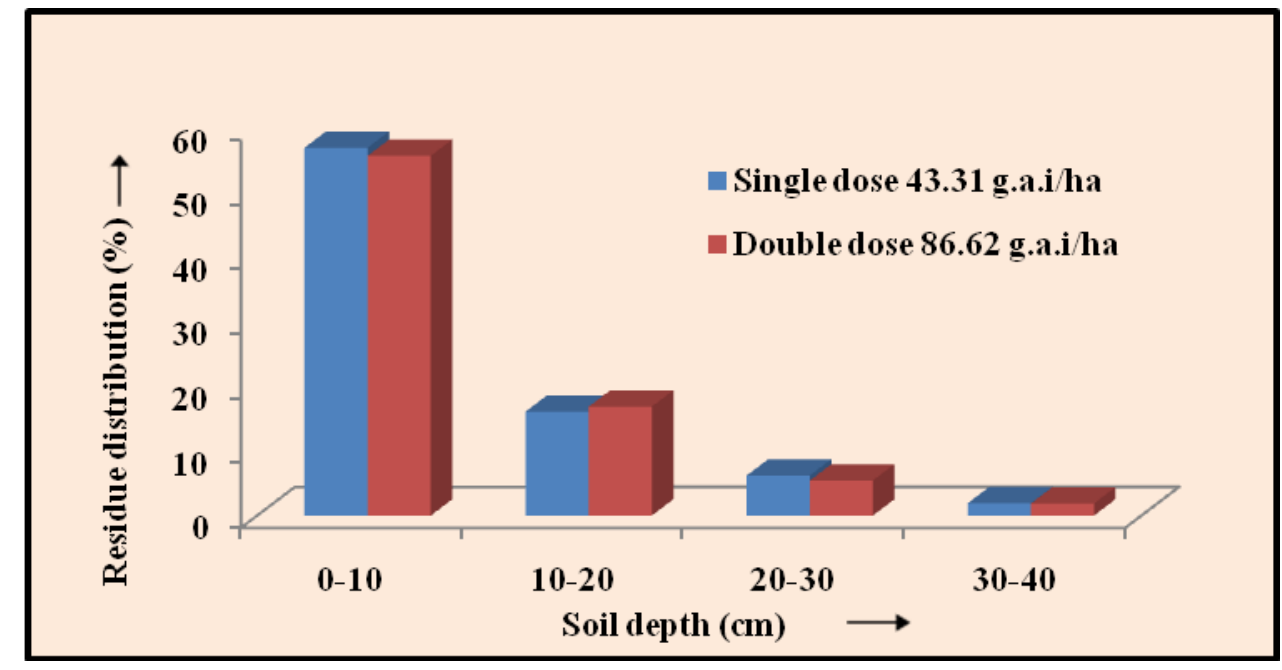

Fig.2 Distribution of indoxacarb residues at different soil depths at single and double doses

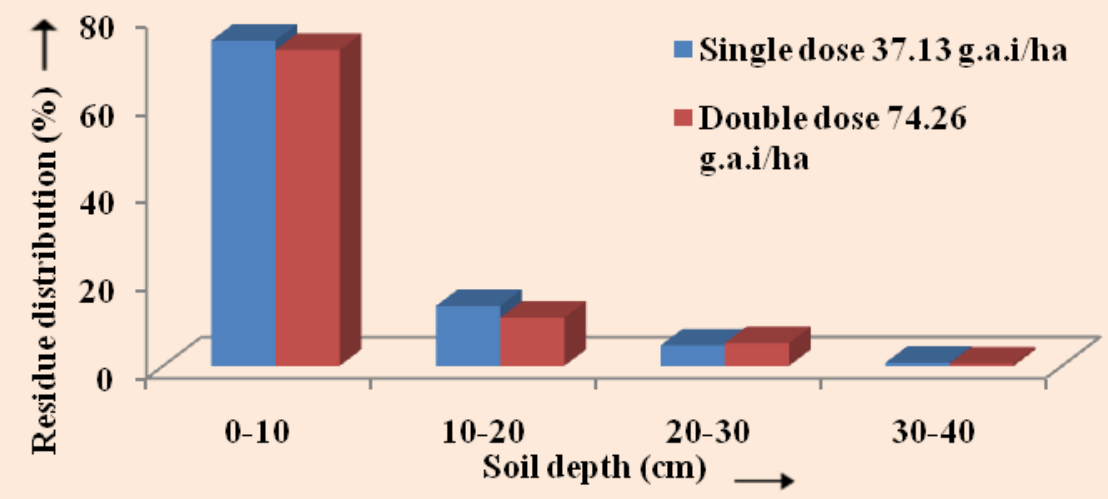

Diuron concentrations in water collected in the lysimeters varied in detected samples from 0.02 to $6.29 \mu \mathrm{g} \mathrm{L}^{-1}$. The average mass of leached diuron in the lysimeters was 9.013 $\mu \mathrm{g}$, representing $0.08 \%$ of the amount applied. Losses of 0.02 and $0.54 \%$ of the applied amount by leaching and runoff, respectively were reported.

Dissipation studies of diflubenzuron, flufenoxuron and novaluron and their effects on bacterial diversity in soils were carried out by Hsiao et al., (2013). The proportion of residual benzoylureas in sterilized soils remained up to $83 \%$ at the end of the incubation, which implied that the dissipation was mainly by microorganisms. All three benzoylureas were not detected below $10 \mathrm{~cm}$ in soil column experiments. Comparison of initial pesticides concentrations $\left(50 \mathrm{mg} \mathrm{kg}^{-1}\right)$, diflubenzuron was detected at $<1 \%$. However, flufenoxuron and novaluron remained at $>30 \%$ and $50 \%$ in $\mathrm{Pu}$ and $\mathrm{Wl}$ soil, respectively after leaching for $70 \mathrm{~d}$. According to Garcia et al., (2006), pesticides recoveries ranged between 92.3 and $109.5 \%$. 
This methodology was used to determine benzoylureas in ground water samples at levels lower than $0.1 \mu \mathrm{g} / \mathrm{L}$.

Campbell et al., (2005), determined that indoxacarb have strong binding with soil tested after 30 days. According to findings of Sun et al., (2012), field trials indicated that the dissipation of indoxacarb enantiomers followed first- order kinetics in soil at two locations. The half- lives of two enantiomers in soil range from 23 to $35 \mathrm{~d}$. The changes of enantiomeric fraction values proved that enantioselective degradation of indoxacarb happened in soil. From above discussion it is clear that very low amount of novaluron as well as indoxacarb residues were detected in soil and water samples in various experiments which were in agreement with our result.

From the results it was concluded that residues were not detected after $40 \mathrm{~cm}$ depth of soil in both the cases and none of the residues of combination product (Novaluron + Indoxacarb) were found in leachates, hence it may be safe for both soil as well as ground water.

\section{Acknowledgments}

The authors wish to express their gratitude to the Head, Department of Chemistry and Department Entomology of CCS HAU, Hisar for providing research facilities.

\section{References}

Anita, Madan, V. K., Chauhan, R. and Kumari, B. 2018. Dissipation Behaviour and Effect of Different Decontamination Processes on Reduction of Residues of Novaluron in Tomato (Lycopersicon esculentum Mill.). Int.J.Curr.Microbiol.App.Sci. 7(05): 648-656.
Campbell, S., Chen, L., Yu, J., and Li, Q. X. 2005. Adsorption and analysis of the insecticides thiamethoxam and indoxacarb in Hawaiian soils. Journal of agricultural and food chemistry, 53(13), 5373-5376.

Chia, L.K. and Zaidel, N.D. 2011. Sorption, degradation and leaching of cypermethrin in Malaysian soils. Malaysian Journal of Chemistry, 13(1), 1-7.

Dagar, P., and Kumari, B. 2014. Leaching behaviour of azoxystrobin in sandy loam soil. African Journal of Environmental Science and Technology, 8(8), 448-454.

Das, P., Pal, R., Chowdhury, A. 2008. Influence of biotic-abiotic factors on the degradation of novaluron in tropical soil. Inter. J. Environ. Sci. Tech., 5 (3), 425-429.

Eliana, F.G.C.D., Cláudio, A.S., Oscarlina, L.S.W., Leandro, C., Antonio, B.V. and Alicio A.P. 2009. Environmental behaviour of metolachlor and diuron in a tropical soil in the central region of Brazil. Water, Air and Soil Pollution, 197, 175-183.

FAO, 2003. Novaluron: FAO Specifications and Evaluations for Plant Protection Products, Food and Agriculture Organization of the United Nations, pp29.

García, M. G., Galera, M. M., Martínez, D. B., and Gallego, J. G. 2006. Determination of benzoylureas in ground water samples by fully automated on-line pre-concentration and liquid chromatography-fluorescence detection. Journal of Chromatography A, 1103(2), 271-277.

Ghosal, A., Dolai, A.K. and Chatterjee, M.L. 2016. Bioefficacy of new ready mixed insecticide (novaluron $5.25 \%+$ indoxacarb $4.5 \%$ SC) against pigeon pea pod borer (Helicoverpa armigera 
Hubner). Legume Research, 39 (1), 135 139.

Halimah, M., Nashriyah, M., Tan, Y. A., and Ismail, S. 2005. The adsorption coefficient (Koc) of chlorpyrifos in clay soil. Journal of Nuclear and Related Technologies, 2(2), 23-30.

Hewa-Kapuge, S., McDougall, S. and Hoffman, A. A. 2003. Effects of methoxyfenozide, indoxacarb, and other insecticides on the beneficial egg parasitoid trichograma near brassicae (Hymenoptera: Trichogrammatidae) under laboratory and field conditions. Journal of Economic Entomology, 96(4), 1083-1090.

Hsiao, Y. L., Ho, W. H., and Yen, J. H. 2013. Vertical distribution in soil column and dissipation in soil of benzoylurea insecticides diflubenzuron, flufenoxuron and novaluron and effect on the bacterial community. Chemosphere, 90(2), 380-386.

Michand, J.P., Grant, A.K. 2003. IPMCompatibility of Foliar Insecticides for Citrus: Indices Derived from Toxicity to Beneficial Insects from Four Orders. $J$. Insect Sci., 16, 3-18.

Pesticides, A. 2000. National Registration Authority for Agricultural and Veterinary. Chemicals Public Release Summary on Evaluation of the New Active Indoxacarb in the Product DUPONT STEWARD EC INSECTICIDE.

Sun, D., Qiu, J., Wu, Y., Liang, H., Liu, C., and $\mathrm{Li}, \mathrm{L} .2012$. Enantioselective degradation of indoxacarb in cabbage and soil under field conditions. Chirality, 24(8), 628-633.

\section{How to cite this article:}

Anita, V.K. Madan, Sushil Ahlawat and Reena Chauhan. 2018. Leaching Behaviour of Combination Product (Novaluron 5.25\% + Indoxacarb 4.5\% SC) at Different Depths of Sandy Loam Soil. Int.J.Curr.Microbiol.App.Sci. 7(12): 260-266.

doi: https://doi.org/10.20546/ijcmas.2018.712.032 